\section{"ONCE UPON A TIME" : SOME FLEETING SIDELIGHTS ON CONTEMPORARY WESTERN POETRY}

\section{Reinhold Grimm ${ }^{1}$}

Once upon a time, there were literary critics and historians in the West, i.e., in Europe and in North America, who prided themselves on being able to subsume the entire development of modern--and likewise, in those bygone years, contemporary--lyric poetry under a single all-embracing rubric. Or, to be fair, if they didn't expressly advocate such a rubric, they surely used and proclaimed an equally ambitious, equally all-inclusive principle. Perhaps the most important and most widely known proponent of this approach and, as it turned out, both dictatorial and complacent attitude was the eminent German scholar Hugo Friedrich, who held the chair of Romance Literatures at the University of Freiburg im Breisgau. In 1956, Friedrich authored a rather slim albeit immensely influential volume entitled Die Struktur der modernen Lyrik ("The Structure of Modern Poetry") after having published impressive studies and monographs on Descartes and Dante, Montaigne and Calderon, among others. However, not only did that novel if seemingly modest book make an immediate splash, but it has also seen an amazing

\footnotetext{
${ }^{1}$ Professor of German and Comparative Literature, University of California-Riverside.
}

number of new editions since it first appeared, and has been translated into over a dozen languages. In point of fact, many people, and for many years, came to regard Die Struktur der modernen Lyrik as a kind of poetic oracle, indeed as a veritable ars poetica in terms of modernism and true contemporaneity.

What were--or are, for the volume is still in print, I believe--the basic ideas, the major tenets and theses, propagated by Hugo Friedrich $?^{2}$ The answer, apparently complex, is clear and unequivocal nonetheless. First of all, modern poetry as conceived by Friedrich originated in France, with Charles Baudelaire's Les Fleurs du mal ("The Flowers of Evil") of 1857 and, later on, with Arthur Rimbaud and Stéphane Mallarmé in particular; moreover, it continued to manifest itself, according to the German scholar, as an essentially French phenomenon although, by extension over the decades, also as a Spanish and Italian one. A glance at the

\footnotetext{
2 For the following, see Hugo Friedrich, Die Struktur der modernen Lyrik : Von Baudelaire. bis zur Gegenwart (Hamburg: Rowohlt Taschenbuch Verlag, 1956) loff.; I am using the 6th edition ("76.-85. Tausend") of June 1962.
} 
very structure of "The Structure of Modern Poetry"---at its quantitative layout, if I may say so---proves to be quite illuminative in that respect. For, after a brief and both historical and programmatic introduction, roughly two thirds of Friedrich's investigation is devoted to those three towering French masters from the second half of the 19th century, whereas the whole of "European Poetry in the 20th Century" (thus the already suspicious chapter heading) is accorded a bare third of it at best ... featuring, as might be expected, the literatures of France, Spain, and Italy once again. And what applies to the discursive and interpretive portions of this longtime seminal book applies to its sizable appendix of exemplary verse as well: the selection we are offered betrays the selfsame 'structural' imbalance---or, I am afraid, the author's plain prejudice---as does the preceding text itself. No fewer than 27 of the 30-odd poems amassed by Friedrich are of French, Spanish, or Italian provenance ; on the other hand, T.S. Eliot, with excerpts from The Waste Land and Four Quartets, figures as the lone and almost token representative of modern poetry written in English; and even from Friedrich's native German-astoundingly or, on closer scrutiny, not so astoundingly, after all--just a marginal couple of poems, five altogether, were ultimately deemed worthy of inclusion. (Three are by Gottfried Benn, and one each by Karl Krolow and Marie Luise Kaschnitz.) No poetic utterances from Slavic or the remaining non-Romance European idioms can be found, much less from non-European literatures or languages.
A threesome of principal concepts serves to form the multiple but unison---or, at any rate, most coherent---slogan of Hugo Friedrich's authoritative disquisition and evaluation; differently put, these concepts function as a combination of touchstones, so to speak, for his vast and yet strangely limited subject matter. They comprise, firstly and in general the twin ideas of "dissonances and abnormality" (Dissonanzen und Abnormität) and, secondly and further generalized, the overall methodological conviction that solely "negative categories" are capable of grasping the structure (and essence) of modern poetry. While the latter can easily be shown to reign throughout Friedrich's discourse, the former, needless to say, entail a whole host of related and/or subordinate notions as his discussion unfolds. From the beginning, for instance, he insists that what basically informs truly modern poems is an "obscurity" (Dunkelheit) which at once entices and captivates as well as confuses and disorients the reader. Such a coincidence of fascination and incomprehensibility naturally amounts, we are told, to a genuine dissonance, or discordance. And it is an intentional one, Friedrich adds with reference to Baudelaire and Benn: for there lies a certain glory in not being understood; poetry aims at rendering unintelligible precisely that which is decisive; the poet indulges in things of whose significance nobody actually deserves to be persuaded. As the Italian Eugenio Montale formulated it so provocatively : "No one would compose verses if the problem of poetry consisted in 
explaining oneself in getting something across." 3 Everywhere, says Friedrich, chiming in contentedly if exaggerating (and contradicting himself) a bit---everywhere among present-day poets, one observes a tendency towards standing aloof, as much and as long as possible, from conveying any unambiguous implications or messages. Or in his own words:

Das Gedicht will vielmehr ein sich selbst genügendes, in der Bedeutung vielstrahliges Gebilde sein, bestehend aus einem Spannungsgeflecht von absoluten Kräften, die suggestiv auf vorrationale Schichten einwirken, aber auch die Geheimniszonen der Begriffe in Schwingung versetzen. ${ }^{4}$

Modern poems, according to Friedrich, wallow in self-sufficiency, are radiant with multivalent meanings, and constitute a dense and suspenseful network of absolute forces affecting, suggestively, the subliminal layers of the mind, yet also setting the mysterious zones of conceptuality vibrating. In sum, they lead the reader astray, to the realm of the unfamiliar and unfathomable; they deform and distort, indeed alienate, our consciousness and its projection, reality. (I trust I need not emphasize that this "alienation" is anything but Bertolt Brecht's famous Verfremdung, which has a clarifying and even didactic effect; rather, it is its very opposite.) Friedrich goes on:

${ }^{3}$ I am quoting somewhat freely, trying to give the gist of Montale's dictum; hence, compare ibid. 10 .

${ }^{4}$ Ibid. $10 f$.
Jene dissonantische Spannung des modernen Gedichts außert sich auch in anderer Hinsicht. So kontrastieren Zuge archaischer, mystischer, okkulter Herkunft mit einer scharfen Intellektualitat, einfache Aussageweise mit Kompliziertheit des Ausgesagten, sprachliche Rundung mit gehaltlicher Ungelostheit, Prazision mit Absurditat, motivische Geringfugigkeit mit heftigster Stilbewegung. Das sind teilweise formale Spannungen, und oft nur als solche gemeint. Aber sie treten auch in den Gehalten auf. ${ }^{5}$

The tensions and peculiarities, catchwords and alleged values here listed---mysticism versus intellectualism, simplicity versus complexity, precision versus absurdness, and so on---ought to be telling and eloquent enough, it seems to me; yet no less immediately obvious and convincing ought to be the fact that they undeniably contravene poetry's age-old emotional allure and formal equilibrium, its proverbial 'organic unity' handed down from Aristotle to Kant and way beyond, and distinguishing, above all, the rich and manifold verse of German Classicism and Romanticism, the so-called Erlebnisdichtung ${ }^{6}$ based on personal and subjective experiences. By contrast, Friedrich's representative poets of modernism, he assures us, are involved in

\footnotetext{
${ }^{5}$ Ibid. 11.

${ }^{6}$ See A Glossary of German Literary Terms. Second, revised and enlarged edition. Ed. E.W. Herd [and] August obermayer (Dunedin, N.Z. : Department of German [of the] University of Otago, 1992) 82.
} 
their doings not as private persons but merely as poetizing intellects: they are linguistic operators, cold-blooded artists unleashing their imagination and transmutative craft at will. Instead of an appeal to the emotions and the sense of beauty, what exudes from their works reveals itself, more often than not, as sheer aggressiveness, as wild and dramatic onslaughts resulting in mental shocks as it were, and in readerly consternation and perplexity; or else, the reader is faced with, and puzzled by, autonomous verbal movements, meaningless series of sounds, and unmeaning sequences of in-and decreasing intensity, not unlike the abstract interplay of autonomous colors and contours in modern painting. All of which must of necessity, create the impression of utmost--and in itself contradictory---abnormality, says Friedrich, just as it also accounts for the chronic "non-assimilability" (Nichtassimilierbarkeit) of modern poetry as a whole.

I could continue along these lines, enumerating sundry additional notions as they ensue from Friedrich's key concepts and their common methodological denominator. For example, that he singles out and lauds the French pre-Surrealist from the late 19th century, Lautréamont, as the most farsighted and prolific supplier of appropriate descriptive terminology is doubtless as expressive of his entire approach as is his invocation of a 20thcentury Spaniard (namely, the poet and critic Damaso Alonso) in order to seal his listings for good. Lautréamont's many pertinent characteristics, put forth in 1870 , include anguish and turmoil, disgrace and grimace, somberness, the predominance of exceptions and eccentricities, a bent for most forceful and extreme ruptures, indeed for nothingness, and, of course, the inevitable obscurity, which Friedrich then supplements, from a variety of sources with cues such as dissolution of what is familiar, forfeit of regularity, incoherence, fragmentation, brutal suddenness, and lightnings of destruction ; to top it all off, Alonso's summary dictum, first pronounced in 1932 and iterated in 1955, finally runs as lapidarily yet explicitly as could be : "Nowadays, there is no expedient way of defining our art [of poetry] other than by negative categories."7 But lest we get lost in Friedrich's overabundance of graphic details, let me quote him once more at some length, because the passage in question, rather than simply compiling bits and pieces, attempts to situate the phenomenon of modern poetry in its overall historical context. It reads :

Bis an die Wende zum 19. Jahrhundert, teilweise darüber hinaus, stand die Poesie im Schallraum der Gesellschaft, war erwartet als ein idealisierendes Bilden geläufiger Stoffe oder Situationen, als heilender Trost auch in der Darbietung des Dämonischen, wobei die Lyrik selbst zwar als Gattung von anderen Gattungen unterschieden, doch keinesfalls über sie gesetzt wurde. Dann aber geriet die Poesie in Opposition zu einer mit

\footnotetext{
${ }^{7}$ See Friedrich, Die Struktur der modernen Lyrik 15.
} 
okonaomischer Lebenssicherung beschäftigten Gesellschaft, wurde zur Klage uber die wissenschaftliche Weltenträtselung und über die Poesielosigkeit der Offentlichkeit ; ein scharfer Bruch mit der Tradition entstand ; dichterische Originalität rechtfertigte sich aus der Abnormitat des Dichters ; Dichtung gab sich als Sprache eines in sich selbst kreisenden Leidens, das keine Heilung mehr anstrebt sondern das nuancierte Wort ; als reinste und höchste Erscheinung der Dichtung wurde nunmehr die Lyrik bestimmt, die ihrerseits in Opposition trat zur übrigen Literatur und sich zu Freiheit ermächtigte grenzenlos und rücksichtslos alles zu sagen, was ihr eine gebieterisch Phantasie, eine ins Un bewußte ausgeweitete Innerlichkeit und das Spiel mit einer leeren Transzendenz eingaben. ${ }^{8}$

Any and all of these changes, Friedrich persists, are most faithfully mirrored in said categories.

Still, it took only four years after the publication of his book until, in 1960, a second volume dealing with modern poetry, and aspiring to all-inclusiveness, appeared in Germany. This time, though, it was not primarily an investigation but a huge anthology, albeit with a sizable and weighty preface ; nor was its author a seasoned scholar but rather a fairly youthful critic if,

\footnotetext{
${ }^{8}$ Ibid. 13 f.
}

primarily, already seasoned poet, and one of the finest to boot. What I am talking about is, as you might guess, the massive 421-page tome Museum der moderne Poesie ("A Museum of Modern Poetry") by Hans Magnus Enzensberger. ' He, too, proclaimed --once upon a time--a "global idiom" (Weltsprache) spoken by all truly modern poets ; and he, too, conceived as its development an ever-spreading irreversible process. Further major criteria Enzensberger's contribution evidently shares with Hugo Friedrich's comprise the following: the idea of modern poetry's innate difficulty and, thus, necessary obscurity, indeed negativity (yet with the important modification that the reverse of every poetic destruction is the construction of a new poetics) : the dual concept of the modern lyricist as a profoundly erudite poeta doctus, on the one hand, but also, on the other, as a mind perforce opposed to contemporary society ; and, last but surely not least, the general insight that the modern poem, whenever and wherever it may have emerged, has its roots in the mid-19th century, i.e., in Baudelaire's Fleurs du mal of 1857 (and likewise, adds the anthologist quite matter-of-factly, in Walt Whitman's Leaves of Grass of 1855). "Die lautlosen Katastrophen der Sprache," as Enzensberger specifies with an ingenious image "geschehen nicht von einem Tag auf den andern, auch nicht von einer Generation zur andern. Sie bereiten sich lange vor."

\footnotetext{
${ }^{9}$ Museum der modernen Poesie, eingerichtet von Hans Magnus Enzensberger (Frankfurt am Main: Suhrkamp, 1960); for the following, see his "Vorwort," pp. 8ff.
} 
Indeed, those "silent catastrophes" of poetic language extend not just over years and decades but over centuries. For were they not, in our case prefigured as early as around 1800 : in the thought of, say, Novalis, that precocious and both visionary and lucid German Romanticist? Here again, the contributions of the scholar and of the poet are in full agreement.

However, as I already intimated, there obtain between them considerable differences as well. The supposedly radical break with tradition, for instance, which Friedrich claims to descry is viewed by Enzensberger much more dialectically--sit venia verbo--and, hence, more realistically: to wit, as a conscious and productive embracing of the past no less than a breaking away from it. (Federico Garcia Lorca's and T.S. Eliot's harking back to the 17 th centrury, to the poetry of Gongora and to the Metaphysical Poets, respectively, are typical cases in point.) Similarly, Enzensberger is firmly convinced that a poetics of modern poetry cannot be disposed of in strictly normative terms ; all one can do, he maintains, is collect and display its parts precisely as in a "museum." And hasn't he, in fact, admirably succeeded in doing so? But the three most salient features differentiating Enzensberger's approach from that of Friedrich arise from their divergent methodological and individual attitudes: towards their very subject matter to begin with; furthermore, towards its sociopolitical and historical implications; and, in the long run, towards their own persuasions and theses and the ultimate or preliminary results they felt they had achieved.
First and foremost, then, what we instantly notice in the pages and chapters of the Museum der modernen Poesie is an enormous expansion compared to the confines of Die Struktur der modernen Lyrik, an expansion, moreover, manifesting itself not merely quantitatively at large--a remarkable growth of poets and poems from English and German letters can be observed, for instance--but doubtless amounting also, more momentously yet, to a vast geographical extension in especial. This is to say that Enzensberger's assemblage of modern poetry, in contrast to Friedrich's lopsided French and Pan-Romance bias and narrowness, ${ }^{10}$ encompasses all but the entirety of Europe, incorporating various Slavic and Scandinavian literatures as well as those of Hungary, Greece, and the Flemish-speaking Belgium, among others ; as a matter of fact, even Turkish lines and stanzas have been allowed to put in an appearance! Still, what needs must strike us here as by far most noteworthy is, if only at first sight, the anthologist's inclusion of modern poetic activities overseas. That North America has been taken into due account goes of course without saying; however, both Central and South America also figure prominently, as do the West Indies (represented by Aimé Césaire) and, behold, the African country of Senegal (represented by her erstwhile president, the Nobelist Leopold Sedar Senghor).

\footnotetext{
${ }^{10}$ Hugo Friedrich, The Structure of Modern Poetry: From the Mid-Nineteenth to the MidTwentieth Century. Trans. Joachim Neugroschel (Evanston: Northwestern University Press, 1974)
} 
Nevertheless, there is no denying that the bulk of this overseas verse, Cesaire and Senghor's negritude notwithstanding is a basically Western, or Westernized, subgenre of modern poetry, inspired by and in Europe; in no way does the crushing majority of such non-European modernists--in particular, the ones from Latin America--deviate from that European mainstream seen and documented here, for the years from 1910 to 1945 , as a powerful infectious process. And the rest of Africa as well as all Asia (mind you: South, Southeast, and East Asia alike) are conspicuously absent from Enzensberger's anthology anyhow ${ }^{11} \ldots$ unless, that is, we

11 Compare what the anthologist, under the heading "Einschrankung, has to say in this regard: "Einzuraumen ist: Keine Rechnung, die sich an Jahreszahlen halt, kann ohne Rest aufgehen. Uberblickt man die zeitliche und raumliche Entfaltung der poetischen Weltsprache, die sich in jenen funfunddreißig Jahren [i.e., from 1910 to 1945] konstituiert hat, so bemerkt man alsbald, daß sie mit der Entfaltung der gesellschaftlichen Produktivkrafte uberhaupt Schritt halt. Ihre Zentren sind mit den Zentren der technischen Zivilisation identisch. In reinen Agrarlandern, deren Gesellschaft noch von feudalen Normen bestimmt ist, tritt sie erst auf den Plan, wenn die Gewalt der industriellen Produktion diese Normen in Frage stellt: meist mit erheblicher Verspatung. Insofern bedarf die These von der poetischen Weltsprache einer Einschrankung. Doß große Teile Asiens und Afrikas [a remarkable understatement] in diesem Buch vermißt werden mussen, hat hierin seinen vornehmsten Grund. Die fehlenden Lander und Sprachen hat der Prozeß zumeist erst in der Zeit nach 1945 und zum Teil bis heute noch nicht erreicht." Enzensberger, "Vorwort," in Museum der modernen Poesie 14. want to make an exception in the case of the Turks; most of whom, after all, inhabit a part of Asia (albeit Asia Minor, granted). But haven't they long been promoted to honorary Europeans, as it were: namely, as a malicious critic might joke, ever since Turkey joined, or was admitted to, NATO?

Second, and even more revealingly, there are the diverse attitudes of Friedrich and Enzensberger towards the historical and, especially sociopolitical implications of the widespread poetic phenomenon they present and/or investigate and treat. The former, as must be abundantly clear, attributes no social or political relevance whatsoever to modern poetry, stressing its pure isolation instead, i.e., its deliberate, either sorrowful or haughty, rejection of any communication; thus. in consequence thereof, he arrives himself at a suchlike position resulting in the rigorous exclusion of socially or politically committed verse in favor of an avowed herneticism, indeed self-centeredness. Conversely if concomitantly, the latter's position is decidedly more complex. For him, to put it as paradoxically as possible, the very noncommitment of modern poetry constitutes the epitome of its commitment; precisely its being poesie pure turns out to render it poésie engagée (and he doesn't hesitate, in point of fact, to label the quarrel betw'een these two notions as a mere Schein problem, or "sham problem"). Drawing on the pronouncements of his philosophical mentor, the Frankfurt School sociologist Theodor w. Adorno, Hans Magnus Enzensberger decreed in 1960: 
$\mathrm{Da}$ das Gedicht keine Ware ist, dieser Satz ist keineswegs eine idealistische Phrase. Von Anfang an war die moderne Poesie darauf aus, es dem Gesetz des Martktes zu entziehen. Das Gedicht is die Antiware schlechthin: Das war und ist der gesellschaftliche Sinn aller Theorien der poésie pure. Mit dieser Forderung verteidigt sie Dichtung uberhaupt und behalt recht gegen jedes allzu eilfertige Engagement, das sie ideologisch zu Markte tragen mochte. Ubrigens leistet der Gegensatz von elfenbeinturm und Agitprop der Poesie keine guten Dienste .... Antiware, die sich der Manipulation 'pur' widersetzt, sind noch die engagiertesten 'Fertigfabrikate' Majakowskis. Ebenso ist der freischwebendste Text von Arp oder Eluard bereits dadurch poesie engagee daß er uberhaupt Poesie ist: Widerspruch, nicht Zustimmung zum Bestehenden. ${ }^{12}$

From the outset, Enzensberger declares, modern poetry has aimed at putting its products out of the market's reach and influence; the poem--any poem, he insists-has been "the anti-commodity absolute." It is herein, according to him, that the meaning and societal relevance of all those theories of poésie pure reside, each of which shelters and defends poetic creation from abuse, including hasty engagement and ideological consumption. The popular opposition of the legendary "ivory tower" and straightforward

12 Ibid. 15. "agitprop" (i.e., "agitation" and "propaganda" as practiced by Soviet literature) hasn't proved to be exceedingly helpful at any rate, Enzensberger ironically reminds us, for even the crudest and most unambiguously committed verse by Vladimir Mayakovski resists such manipulation 'purely,' just as even the most audacious, most hermetic and freewheeling texts by the Dadaist Hans Arp or the Surrealist Paul Eluard amount to poésie engagée by virtue alone of the simple fact that they are poetry at all: that is to say, protest against, not approval of, the powers that be. Or to adduce yet another outspoken declaration of Enzensberger's:

Was die Diktatur gegen sie [i.e., modern poetry] aufbietet beweist, welche Krafte von ihr ausgehen. So gering, statistisch betrachtet, ihre Ausbreitung ist, so unabsehbar ist ihre Wirkung. Poesie ist ein Spurenelement. Ihr bloßes Vorhandensein stellt das Vorhandene in Frage. Deshalb kann die Gewalt sich mit ihr nicht abfinden. ${ }^{13}$

In a word, poetry, however minimal, is subversive; its mere existence even as a "trace element" (Spurenelement) will call that which exists--the reference is again to the powers that be---forever in question. As Adorno phrased it so outright and succinctly, to quote but two of his pertinent statements: "Any commitment to this world must be canceled so as to fulfill the idea of a committed work of art;and "unswerving

13 Ibid. 16. 
solitude is for today's intellectuals the sole means of possibly

evincing solidarity." 14 (None of which, incidentally, hindered Enzensberger in the least from boldly placing no fewer than eleven poems by Bertolt Brecht--Friedrich, needless to say, doesn't allow of a single one-in the stately halls of his roomy museum although, to be frank, no more than a meager minority of those eleven texts can rightly be termed as sociopolitically, or even historically, committed verse proper.)

Third and last, the scholar Friedrich and the poet Enzensberger differ sharply as far as any re-examination and re-evaluation of their own tenets and theses and once so proudly proclaimed results are concerned. Namely, while the author of "The Structure of Modern Poetry" steadfastly iterated his erstwhile convictions, the compiler and commentator of the "Museum of Modern Poetry" was quite ready and willing to revise his position, and most drastically at that. In 1980, for example, in his "Nachbemerkung"

${ }^{14}$ See Theodor W. Adorno, Noten zur Literaur III (Frankfurt am Main Suhrkamp, 1965) 129 and Theodor W. Adorno, Minima moralia: Reflexionen aus dem beschadigten Leben (Frankfurt am Main: Suhrkamp, ${ }^{3}$ 1962) 22. Also, compare my "Bildnis Hans Magnus Enzensberger: Struktur, Ideologie und Vorgeschichte eines Gesellschaftskritikers," in Reinhold Grimm, Texturen: Essays und anderes zu Hans Magnus Enzensberger (New York [etc.] : Lang, 1984) 44-96 ; here, pp. 86ff. (this essay was first published in 1974).
("Postface") of the two-volume paperback edition of his anthology, Enzensberger recanted precisely the double 'advance and improvement,' so to speak, which had distinguished his approach of 1960 as against Friedrich's geographic narrowness and apolitical isolationism of 1956 and afterwards. Repeating his apodictic judgment according to which modern poetry always calls whatever exists into question, the anthologist had to concede, and did so with. a shrug, that such a promising view amounted to an "exaggeration," to say the least: the "touching belief [ruhrender Glatıbe] in the subversive powers of literature," Enzensberger stated summarily, "has in the meantime been impaired to a high degree." And similar objections, he went on, must be raised to that confident assertion according to which there obtains something like a "global idiom of modern poetry." What comes to light in such ideas, we learn, is but a naive "internationalism lumping everything together." 15

Let me quote some of the subsequent passages in the German original once more, for Enzensberger's 1980 recantation doubtless reveals itself as exceptionally instructive in our context. "Die Ideologie der 'One World'," he says,

von den Amerikanern wahrend des Zweiten Weltkriegs verkundet, von den Nachkriegsdeutschen aus durchsichtigen Grunden gerne

15 For these and the following quotations, see Museum der modernen Poesie, eingerichtet von Hans Magnus Enzensberger. 2 vols. (Frankfurt am Main: Suhrkamp, 1980) II: 786f. 
akzeptiert, in den Vereinten Nationen institutionell verwirklicht und verblaßt, ist politisch spatestens seit 1968 durchschaut und auf den Hund gekommen. So ist auch dieses Museum, wie die moderne Poesie, die es ausstellt, ...von einem ahnungslosen Eurozentrismus gepragt, der einzig und allein die Standards der Metropolen gelten laßt.

Evidently, what is denounced here is not only the meanwhile shopworn ideology of a unified 'One World' as propagated by the Americans and institutionalized by the United Nations, but also the ideological bias of Enzensberger's own ambitious anthology: to wit, its "ignorant Eurocentrism, which simply and solely approves of the standards of the metropoles." The idea of "world literature" (Weltliteratur, a venerable term coined by Goethe, as might be remembered) 16 has thus degenerated, the "Postface" continues to explain, into an "apologetic regulation," indeed an unabashed "lever" (Druckmittel) in the employ of cultural imperialism; all it insidiously engenders is a kind of literary "global market," but which in effect is a "whirlpool" (Strudel) preventing any genuinely indigenous, or autonomous, creation. And Enzensberger concluded:

16 See Goethes Gesprache mit Eckermann (Berlin: Aufbau-Verlag, 1955) 278: "Nationalliteratur will jetzt nicht viel sagen, die Epoche der Weltliteratur ist an der Zeit, und jeder muß jetzt dazu wirken, diese Epoche zu beschleunigen." The entry dates from 31 January 1827.
Diese Kehrseite der Medaille ist in den letzten Jahren immer deutlicher sichtbar geworden, und zwar nicht nur aus politische Grunden. Auch in der literarischen Produktion selber zeigt sich an, daß die Moderne rapide altert. Ihre Weltsprache ist unterdessen in zahllose Dialekte zerfallen. Weit entfernt davon, sich nach den 'klassischen' Mustern zu orientieren, ist die Poesie der letzten Jahrzehnte immer heterogener und regionaler geworden. Ihre Ubersetzbarkeit hat ab-, ihre Mannigfaltigkeit zugenommen. Gegen die Abstraktionen der Ideologie, des Weltmarkts, der Technokratie beharrt sie geradezu storrisch auf dem Besonderen. Fast programmatisch nimmt sich ihr Ruckzug in die Minderheit aus, in die partikularen Interessen, ins Milieu, in die Mundart, in die Subkultur und in den Alltag.

For various reasons, both sociopolitical and literary, the celebrated monolith of a global poetic idiom had disintegrated during those twenty years. In its stead, countless "dialects" had sprung up, and they all were far from emulating the 'classical' paragons of modernism. Rather, poetry had become ever more heterogeneous, ever more regional worldwide; its multifariousness had steadily been on the increase while its translatability had been diminishing. Against scores of abstract ideological, economic, and technocratic odds and generalities, it almost stubbornly persevered in that which is particular, withdrawing near 
programmatically to the realm of minorities, the 'milieu,' the "vernacular" (Mundart), the so-called subculture, and, tout court, to everyday life. This and more of its ilk, as Enzensberger impresses upon us, forms the "reverse [Kehrseite] of the medal"--things of which Hugo Friedrich and his followers never had even the slightest inkling.

And yet, interestingly enough, there still remains a notorious bone of contention on which, no matter how strange it may sound, Friedrich and Enzensberger fully agreed. What I mean is the assessment and/or justification of the artistic, linguistic, and philosophical value of the international school of Concrete Poetry. Friedrich sneered at it, dismissing it as a loathsome "rubble of syllables ground out mechanically," and therefore as of no significance whatsoever; but Enzensberger, too, rejected it, pillorying its German advocates and practitioners (with an untranslatable pun and allusion) as the raving "Movensbande."17 Both of

${ }^{17}$ Unfortunately, I have to quote or cite all this from memory. But of. Movens : Dokumente und Analysen zur Dichtung, bildenden Kunst, Musik, Architektur. In Zusammenarbeit mit Walter Hollerer u. Manfred de la Motte hg. von Franz Mon (Wiesbaden: Limes, 1960) as well as Hans Magnus Enzensberger, Einzelheiten II: Poesie und Politik (Frank furt am Main: Suhrkamp, 1964) 71. Enzensberger's coinage "Movensbande" ('Moving' Gang") ironically evoked, long before the infamous "Gang of Four" (Viererbande) in the People's Republic of China became feverishly and perniciously active, his Frankonian fellow countyman Ernst Penzoldt's latter-day picaresque novel Die Powenzbande: Zoologie einer Familie Penzoldt's gemeinverstandlich dargestellt of 1930. which prompted me--I was myself then perhaps not engaged in, but certainly affiliated with, Concrete Poetry--to examine, delineate, and set forth the historical rootednes and present-day justifiability of this 'movement' that, or so it appeared to me, was not merely another by-product of the overall phenomenon of modern poetry but, in a way, its necessary outgrowth and indeed, its logical outcome and crowning result. And I felt all the more entitled to do so as I had been invited by the Paris-based avant-garde journal Les Lettres speedily to submit a like contribution. So, at the behest of its editor, Pierre Garnier, I blithely embarked on my disquisition, choosing as its heading " 13 Thesen, die neue Lyrik betreffend" ("13 Theses Concerning the Novel Poetry" or, because it was to be published in French, " 13 theses [note the playful internal rhyme sur la nouvelle poésie"). However, since that little essay has already appeared not only in French and in France but also in English and in Italy, of all countries, and even in its original German in a German Festschrift ${ }_{2}^{18} \mathrm{I}$ shall restrict my brief--and, as it will turn out, somewhat abortive--report to the main thrust of my old and, maybe, old-fashioned argument.

${ }^{18}$ Compare Reinhold Grimm, "Treize thèses sur la nouvelle poésie," Les Lettres 33 (1964): 2226, 'Dada--Among Other Things," Studi dell' Istituto Linguistico [Florence] 7 (1984): 5-16, "13 Thesen, die neue Lyrik betreffend," in "Nicht allein mit den Worten" : Festschrift fur Joachim Dyck zum 60. Geburtstag. Hg. Thomas Muller [et al.] (Stuttpart-Bad Cannstatt: Fronmann-Holzbog, 1995) 39-44. 
It is true, like Enzensberger in $1960,{ }^{19}$ I started off by curtly observing that this allegedly modern poetry doubtless dates back about a hundred years. (That was written in 1963, mind you.) Then, however, I plunged headlong, as it were, into what cannot strike us in retrospect as a thoroughly formalistic demonstration. Ever since its inception, I sovereignly declared, modern lyric poetry has disposed of two extreme possibilities: texts for the eye and texts for the ear. Mallarmé, I explained, composed his "Coup de dés" ("Toss of the Dice") almost a century ago; soon thereafter, Guillaume Apollinaire followed suit with his Calligrammes. Just cast a glance at those poems, I said, and you will realize that they are--though surely not exclusively--texts for the eye. In Rimbaud, on the other hand, we find texts, or at least lines, marked for the ear, some of which come pretty close to being pure sound. Compare, for example: "Les roses des roseaux des longtemps dévorées" "The roses of the reeds long since devoured"). Similarly, Georg Trakl wrote: "Oh, die Rosen, grollend in Donnern" ("Oh, the roses, roaring with thunder"). Taken phonetically--as products of 'phonopoeia,' to adopt a more dignified and scientific term-these roses of Trakl and Rimbaud are in effect identical, no matter how different they prove to be in all other respects. ${ }^{20}$

We owe that felicitous term, 'phonopoeia,' to Ezra Pound, as is well known. It denotes the auditory extreme in verse, just as its

19 Cf. Museum der modernen Poesie [1960] 8.

20 For this and the following, see my publications In $\mathrm{n} .18$ above. corresponding term, 'graphopoeia,' designates poetry's visual extreme. And if we now add to them the concept of 'logopoeia'--since I hold we ought to go on the assumption that there are in fact poems which do make sense--we have already arrived at the three major constituent forces propelling the development of modern poetry. Indeed they are the determinant factors of poiesis in general, whether ancient or modren. What distinguishes the avantgardists' outpourings is but the rank and cantankerous growth of both graphopoeia and phonopoeia, while the concomitant logopoeia tends to fall, more and more, into desuetude. Of course, prior to Rimbaud--to return to him for a moment--a conventional poetic language prevailed. Germmatically speaking, its basic model consisted of the triad 'subject--predicate--object' ; in terms of imagery, its similes and metaphors revealed themselves as logical comparisons or 'translations,' based as they were on a proportional equation. (Example: Foot : body $=\mathrm{x}$ : mountain. In other words, the relation of the foot to the entire human body equals that of the lowest part of the mountain to the mountain in its entirety. The seemingly unknown ' $\mathrm{x}$ ' this equation yields is, needless to say, quite familiar, in English no less than in German: namely, 'the foothills' or 'der Fuß des Berges.') Such logical images--first described, by the way, by none other than Aristotle--were common in everyday speech as well as in poetic discourse as was, in both cases, the conventional triadic syntax. Rimbaud's "systematic disordering of all the senses" (his famous dérèglement de tous les sens) simply meant that here a poet, for the first time, had 
recognized the situation, and consciously resolved to change it.

This change proceeded in stages. First, it affected the imagery. The prevalent comparative mode, i.e., the logical deduction (witting or not) of similes and metaphors, was supplanted by an immediate poetic vision--something Gottfried Benn would later on call "primary proposition" (primare Setzung). "As the particle 'like' disappears," said Paul Claudel of Rimbaud, "the two elements of the metaphor appear to him to possess almost the same degree of reality." An excellent illustration of this transition is provided by Ezra Pound's justly famous poem "In a Station of the Metro." I trust you all know it, perhaps even by heart:

The apparition of these faces in the crowd; petals on a wet, black bough. 21

Eventually, the metaphor became completely autonomous, and what had initially been but an unprecedented compression of verbal elements which still betrayed a logical connection to one another was ultimately turned into pure alogical imagery. Yet, all the same, this was only the first stage, for Rimbaud, while thus unleashing the imagery of language, left its structure, i.e., grammar and syntax, for the most part intact. It was the poetry produced around 1910 to 1920 that took the second and final step. Its battle cries were parole in liberta and Lautgedicht, among others: that is to say, the total

${ }^{21}$ Quoted from Museum der modernen Poesie [1960] 76. liberation of the word--in fact, one could rightfully add, that of the syllable and letter, too--as well as a kind of hitherto unheard-of verse nourished with, and totally relying on, sheer sound. And not only did the Italian (and Russian) Futurists and the international crop of Dadaism figure as the protagonists and propagators of this impetuous development, but also, it goes without saying, did the German Expressionists and the French Surrealists even though the former movements quickly came to stand in the forefront. All over Europe and beyond, an ever-enlarging disintegration of the traditional model of poetic language was taking place. Sentences, indeed individual words and already truncated syllables, were unraveled and fell apart. As Benn's estecmed friend Carl Einstein noted, one was tired of clambering about in their choking web.

At this juncture, no doubt, the border zone between language and that which is beyond language has been reached. However, rather than belaboring said Brandungszone or gurtel---"surf belt," as I, poeticizing, actually put it--let me present, without further commentary, some pertinent confessions and proclamations:

Nur die Destruktion der Sprache wird der Beilaufigkeit ein Ende machen ["Only the destruction of language will put an end to casualness and extraneousness"]. Thus the Austrian poet and translator Max Holzer, then one of the very few latter-day (and German-speaking) Surrealists. 
Il faut pulveriser notre langage usé ["It is necessary to pulverize our worn-out language"]. Thus the aforementioned Pierre Garnier, the editor of Les Lettres and himself a prolific concrete and experimental poet.

Das kreative Individuum, von allzu gebahnten Ausdruckswegen umschlossen wie von Mauern, wirft sich in die Sprache selbst ["The creative individual, hemmed in, as by walls, by exceedingly well-trodden paths of expression, launches himself upon language itself']. Thus Hugo von Hofmannsthal, the great and by no means avant-gardist Austrian poet and playwright, storyteller and essayist from the turn of the century. But wasn't he, after all, the author of that signal and seminal "Lord Chandos Letter." one of the earliest testimonies of a fundamental skepticism towards conventional language?

O fraîcheur, ô fraîcheur retrouvée parmi les sources du langage ["Oh freshness, oh freshness recaptured amidst the wellsprings of language"]. Such is the jubilant exclamation of a panegyric from the French Antilles, Alexis Saint-Leger Leger, publicly known by his pseudonym of SaintJohn Perse.

L'homme est à la recherche d'un nouveau langage ["Man is in search of a new language"]. Thus Apollinaire, the Pole and elective Frenchman, who would hardly have made it, I suspect, under his real name (which was Wilhelm A. de Kostrowitzki).

Clearly, the five statements here assembled-and they could be augmented almost at will-evidence three major points: first, the truly international and multilingual nature of the development extending from Rimbaud to the present (at least, that of the 1960s); second, the inner unity of this whole period; third, the ultimate--i.e., positive--meaning of both. For what has been happening in modern lyric poetry, and from our perspective in particular, is by no means merely negative.

Hence, in lieu of 'disintegration,' we had perhaps better speak of 'decomposition.' The term is uncontaminated and neutral, and it demands, of necessity, its complement: 'recomposition.' As Ferdinand Kriwet, a minor German theorist, once expounded: "By decomposition of the literary unit I mean the emancipation of the literary parameters." They are: "volume, pitch, tonality, and duration of the spoken elements, as well as size, face, and font of type plus the distribution of the letters." That these definitions, in however limited a way, mark the culmination of the dual process at issuetexts for the ear and texts for the eye, we recall--ought to be self-evident. Simultaneously and quite naturally, though, the selfsame process aims at the dismantling of a specific language and the search for a new one. It is a double procedure again, occurring in two areas. One of them still lies 
within the boundaries of language and human speech. In it, modern Western poetry transcends its preordained (mostly IndoEuropean) linguistic structures, the established bases of expression. What it arrives at is either an isolating or an agglutinative structure of poetic discourse. And I, an amateurish linguist, ventured to explain:

It is accepted practice . . . to classify languages as being inflectional, rootisolating, or agglutinative. This trisection purports that there are languages--such as those belonging to the Indo-European family--which, by means of their differentiated system of inflection, erect highly complex syntactic structures, whereas others either place their words, unconnected, alongside of each other, or link them together in continuous series or chains. Classical Chinese, for example, is a root-isolating language consisting almost entirely of monosyllabic words. It has no specific forms of the kind we are familiar with: that is to say, it possesses no lexical modifications which convey certain particulars such as number, tense, person, or certain relations such as subject, object, attribute. Any kind of grammatical analysis is impossible. A single word can variously denote an action, a condition, a quality, a direction, a thing, or a person. The function it assumes at a given moment is determined in part by context, in part by word order. Arrangement is everything. Conversely, the language of the Greenland Eskimos operates in exactly the opposite manner. A typical example of a language of the third sort, this agglutinative tongue forms its sentences out of individual words which, though very few in number, are remarkably rich in their fields of meaning. Also, they are capable of carrying long chains of affixes, with each stem absorbing a maximum number of referential connections. In the Eskimoan language, it is extremely difficult to ascertain where one word ends and another begins. Indeed, one cannot really differentiate between word and sentence, because every utterance consists of a continuous holophrastic sound. ${ }^{22}$

Yet how about Thai, a tonal language like Chinese but, as far as I know, not a totally isolating one? How does it function? I frankly admit that I don't have the faintest idea. One thing, however, is sure: Nowhere, despite appearances, does my own Eurocentrism--once upon a time--come more blatantly to the fore than in such and similar ruminations. ${ }^{23}$

Nevertheless, modern experimental poetry (and this includes, for instance, the Noigandres Group from Brazil as well as Japanese concrete poets) virtually abounds,

${ }^{22}$ Grimm, "Dada--Among Other Things" llf.

${ }^{23}$ Compare esp. my "Versuch uber Lyrik und Sprachbau," in Reinhol Grimm, Strukturen: Essavs zur deutschen Literature (Gottingen: Sachse u. Pohl, 1963) 172-96. 
both in theory and practice, with correspondences to those two non-European languages singled out in my venturesome description. ${ }^{24}$ Understandably enough, I can only hint at a few short examples; and, likewise understandably, they are derived from the literatures written in German. Isolating, beyond dispute, is the following poem (or lyrical permutation) by the Bolivian-born Swiss Eugen Gomringer, one of the founding fathers of Concrete Poetry:

$\begin{array}{ll}\text { baum } & \text { (tree } \\ \text { baum kind } & \text { tree child } \\ \text { kind } & \text { child } \\ \text { kind hund } & \text { child dog } \\ \text { hund } & \text { dog } \\ \text { hund haus } & \text { dog house } \\ \text { haus } & \text { house } \\ \text { haus baum } & \text { house tree } \\ \text { baum kind hund haus } & \text { tree child dog house) }\end{array}$

This is about the easiest translation I have ever done. But things are not always that simple. Consider, if you will, another poem by Gomringer. It is one of those he composed in English to begin with:

americans and apricots

american apricots

apricot americans

apricots and americans

${ }^{24}$ For an impassioned survey of and from the heyday of that experimental poetry in general, of. Pierre Garnier, "Jungste Entwicklung der internationalen Lyrik," in Zur Lyrik-Diskussion. Hg. Reinhold Grimm (Darmstandt: Wissenschaftliche Buchgesellschaft, 1966) 45169 (Garniers Essay was penned in 1964).
Merely two words (instead of the previous four) are being permuted in this nice piece of satire, prejudice, and European snobbishness yet it is well-nigh impossible to render Gomringer's second text immediately--i.e., without substantial changes--into German. Why? Because two elements are involved here. nouns and adjectives, not just nouns alone, as in the foregoing example; and because English is much more of an isolating than an inflectional language. Indeed it is, with its dearth of inflections, as closely related to Chinese as could be ... while German in turn, bent as it is on fabricating veritable verbal monsters--at least some of us will be painfully aware of them--tends to outdo even the most Eskimoan Eskimo tongue with its agglutinations. Take, for instance, the Austrian Konrad Bayer's untranslatable tapeworm of a word: mauerwerkzeugewehrlaufschrittweisendrahtverhautanahebeinahelmesserwacht [etc.]

As must be obvious to anyone conversant with German, not only does this linguistic/poetic monstrosity comprise a single 21-syllable word or sentence, but its overlapping vocables also form, at one and the same time, a constant internal concatenation (as, for instance, in gewehrlaufschritt, which contains and therefore evokes both gewehrlauf $f_{2}$ "rifle barrel," and laufschritt, "double-quick," and so on). And must I expressly emphasize that both Gomringer and Bayer demonstrate the utter' puristic extremes of such branches of experimentation? If you want to convince yourself of the true lyrical value inherent in isolating or agglutinative poetic structures 
imposed on, or gleaned from, inflectional German, I suggest that you study Georg Trakl on the one hand, ${ }^{25}$ or even the extremist August Stramm, and on the other, Else Lasker-Schuler or even the monomaniac Arno Holz. Specifically for holophrastic verse, I recommend Lasker-Schuler's wonderful poem "Ein alter Tibetteppich" ("An Old Tibetan Rug") with that equally untranslatable line which runs "maschentausendabertausendweit." As to isolating poetry, any mature line by Trakl will speak for itself.

The other area through which our general development proceeds lies already beyond the frontiers of language. Gradually, a twofold transformation takes place during this process: a) one from letter to picture; b) one from phoneme to sheer sound. In the end, the poem, an erstwhile verbal construct, has become a piece either of graphic art or of modern music of sorts, indeed of unmitigated noise. (Abstract, aleatory, and arbitrary designs as well as sundry kinds of cackles and cacophonies have the upper hand, needless to say.) of course, instead of speaking of the 'frontiers of language,' I might as well have spoken of the 'general linguistic [and, above all, poetic] front line' : both terms, or images, allude to the selfsame fertile strip between language and what is beyond any language. But let's face it, this is, as often as not, a pretty comic strip, if only involuntarily. On the other hand, however, it likewise is that very "surf belt," that pathetically wide border zone, which we

25 Compare my "Georg Trakls Sonne," in Grimm, Strukturen 146-71. have envisaged from the beginning. Language, dissolved into its various elements, here vanishes and reappears continually. The static artifact has given way to a dynamic process. Hence, isn't it precisely that zone which every text of Concrete Poetry, in the vein of Futurism and Dadaism in particular, needs must strive to attain, hoping to blend with it completely? Such poems no longer transcend in alien nonetheless preexisting linguistic structures, but rather in novel and artificial ones, no matter how crude and uncouth they may be. Even more so, this applies, mutatis mutandis, to the ensuing crossover into picture or sound. In conclusion, its overall gist was rephrased by me, a reticent German, in duly grandiloquent French style (for, as you will remember, this whole youthful disquisition of mine was conceived and penned for publication in an enthused avant-garde journal in France). So, please, bear with me:

Just as the first forms of organic life originated in the shallows between the warm primordial sea and the slowly emerging continents, so, too, has the modern experimental poem--whether concrete or visual or acoustic, or what have you--come into being, and finally into its own, between language and language's 'other.' In lieu of 'language' and, more correctly again, 'what is beyond any language,' one can, of course, quite simply say 'meaning' and 'sound' or, as the case may be, 'letter.' In fact, one has to. "We must never forget that the composition of the acoustic poem is a dialectical composition, the two poles of which are sound and meaning." This insight 
of one of my former students (now himself a professor long since) is universally valid. Whoever attempts to overrate, or turn into an absolute, any of these poles--either meaning, on the one hand, or sound and/or letter, on the other--is prone to killing the poem. And to kill the poem inevitably leads to barbarism. Any reduction of the word to nothing but a programmatic message, an empty sound or noise or a self-satisfied graphic design, will render it equally inhuman. No poem, I proclaimed, without SENSE . . . nor, to be sure, without SENSES! And thus pontificating and, luckily, declaring myself against any modish excesses--poetic, pseudopoetic, or otherwise-I concluded by pointing out that, to all intents and purposes, more than enough poetry was still being produced within the boundaries of conventional language, even traditional imagery. There have always been many varieties of it, ranging from didactic and iconic verse to song and ballad, and actually constituting the overwhelming majority of the entire Western--and, I am altogether positive about that, not merely Western--lyrical output. To believe that solely and exclusively texts of one's own persuasion are possible, or 'progressive,' at a given time has been a fundamental delusion of any and all poetic isms, both previously and more recently.

Well, however pompous and 'francophone' this disquisition turning into self-criticism may have sounded at first, it was and is, at long last, rather serious all the same. Without fail, I can claim to have arrived, as early as 1964, and in spite of my avowed sympathies, at a fairly sound and realistic concept of diversity not dissimilar to that of the self-critical anthologist Hans Magnus Enzensberger, and, moreover, to have propounded it, in no uncertain terms, not only then but also in 1984 and, once more, in 1995. What has sorely been missing, though, in these ideas of mine put forward since 1964 is an insight, comparable to that gained by Enzensberger in retrospect, into their naive and unconscious Eurocentrism; besides, and quite unlike Enzensberger's theorizing again, mine never did engage in a discussion of the sociopolitical aspects and implications of modern poetry. Nor is there-- and, worse yet, neither in my "13 Theses" of 33 years ago nor in Enzensberger's "Preface" of 1960 or even "Postface" of 1980--any mention whatsoever, except in passing or implicitly, of the ancient and nowadays widely rejuvenated assistant role of literature's Schwesterkunste ("sister arts," as Bertolt Brecht used to call them) of music, on the one hand, and fine art, on the other. (That Hugo Friedrich didn't dream, much less think or talk, of a suchlike sisterhood goes without saying.) Still, hasn't the influence of graphic and musical components on modern and, above all, contemporary verse been growing and expanding for decades? Isn't the role they play, being combined and, in fact, merging with lines and strophes, ever so vital in present-day poetry? Whether as oldfashioned iconic poems and newfangled patterned ones or as chansons and ballads, plain songs and protest songs, and even rap: ${ }^{26}$ those hybrid genres have now long become

26 Cf., for instance, Christoph Ribbat, "Borrowed Beats and Native Tongues 
an integral part of today's literary scene, and decidedly not just on its Western boards, so to speak, but on an international level, too (none other than modern Thai music and poetry would most probably offer, from all I can judge, an especially striking example of an accomplished non-European song culture .... and, perhaps, likewise of its problems, its risks and perils). However, both genres, or subgenres, in question require in-depth and sizable investigations of their own, as I shall try to demonstrate in the last of my five lectures, the one devoted to "Poems and/as Pictures", 27 the interplay of poetry and music, unfortunately, has to be set aside here and passed over for obvious lack of time and spare.

Diversity, I said, reveals itself as the overarching concept that can be gathered from Hans Magnus Enzensberger's retrospection of 1980 as well as from my much more limited but continued explorations and modest proposals. Granted that it doesn't amount to that easy and convenient all-inclusive principle anymore which we were wont to espouse once upon a time, yet it still provides a workable rubric or heading or, if you wish, common denominator, no matter how loose, or even

Multicultural Rap in Germany," GermanAmerican Cultural Review (Spring 1997) : 1417.

27 See Reinhold Grimm, "Poems and/as Pictures: A Quick Look at Two an a Half Millennia of Ongoing Aesthetic Intercourse," in From Ode to Anthem: Problems of Lyric Poetry. Ed. Reinhold Grimm and Jost Hermand (Madison and London: University of Wisconsin Press, 1989) 3-85. vague, it might be. What is all-important, however, in our context is the indisputable fact that this concept, as reduced as it is, holds true for modern and contemporary poetry in the United States and, to a lesser degree, the United Kingdom as well, and that the situation it so aptly characterizes hasn't changed a bit, in those English-speaking countries as little as in the German-speaking community. Diversity, I repeat, reigns everywhere, and it reigns supreme. This is particularly manifest in the literature of the United States. An up-to-date survey contained in one of the best and most reliable reference works begins, placing the category of "difference" equaling diversity at its very center, with sweeping statements such as the following:

Minoritatenangehorige und Fraluen (unterprivilegierte gesellschaftiche Gruppen) finden zunehmend Berucksichtigung. Die zertrale literaturwissenschaftliche Kategorie heißt derzeit 'Differenz.' Die Vorstellung von einem nationalen kulturellen Erbe weicht der Idee von einer kulturellen und damit auch literarischen Vielfalt auf sprachlicher, ethnisher, geschle chtsspezifis"cher/sexueller, popularer/elitarer und klassen-, regional und millieubedingter Grundlage.

According to Jean-François Lyotard, whose influential treatise La condition postmoderne of 1979 is approvingly invoked in the survey, our present age and literature in their entirety 
are distinguished by the "universality of heterogeneity." 28

Doubtless, these and other societal and thematic differences--the emergence of formerly underprivileged sections such as minorities and women, the assertion of ethnic, linguistic, and gender-specific (feminist, gay, lesbian) as well as of popular, regional, and subcultural multifariousness-all are applicable to contemporary American poetry to the full extent, indeed almost beyond measure, but they also are, and no less undoubtedly, reminiscent of that global diversity identified by Enzensberger in his reassessment, as are their accompanying formal and structural differences suggestive of those multifarious modes of expression identified by myself. In point of fact, even the general trend I have sketched with regard to present-day poetry's worldwide development, in theory and practice alike, and to its towering modern antecedents can immediately and fully be discerned in American poetry as it has developed since about the end of World War II. For just as the critic and historian Hugo Friedrich once went back to Baudelaire and the subsequent French and Pan-European modernism, so, too, did American New Criticism go back to Ezra Pound and T.S. Elisot, and did the so-

28 Compare Dieter Meindl, "Die Gegenwartsliteratur der USA," in Kritisches Lexikon zur fremdsrachigen Gegenwartsliteratur. Hg. Heinz Ludwig Arnold (Munchen: Edition Text + Kritik, 1983ff.) VII: 1-31; here, p. 1. As for contemporary poetry in the United Kingdom, which is far less typical anyway, see Thomas Kullmann, "Die englische Gegenwartsliteratur," in ibid. 1-33 (all entries in this lexicon have separate pagination). called 'high modernists' following in their footsteps. The course American verse has taken from the mid-1950s onward is sufficiently known: it started off with the extroverted 'beatniks' (think of Allen Ginsberg's Howl) and the introverted 'confessional poets' as best represented by Robert Lowell, then led to the 'Black Mountain' and 'deep image' groups headed by Charles Olson and Robert Bly, respectively, and has since come to a preliminary end, it seems, with the 'New York School of Poetry' under John Ashberry and the amorphous mass of what laconically figures as 'language poetry. ${ }^{29}$ Upon my word, the portrait could hardly be more varicgated, more motley, could it? Or as the survey quoted above has already summed it up, both briefly and nicely as well as quite soberly: "Vermeidung des Programmatischen und Fehlen eines Epochenstils kennzeichnen

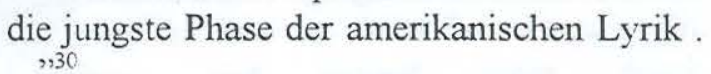

Indeed, the "avoidance of setting up programs"--for all the engaged vacillation at work--as well as the "absence of a [uniform] epochal style!" But such are likewise, no question about it, two of the major characteristics of present-day poetry written in German. If unalloyed hermetic and nonpolitical verse in the strongly seductive wake of Gottfried Benn had been dominant in the 1950s and early 1960s, and if hosts of

29 For more details and some critical remarks, see David Rigsbee, "The Materialist Muse: Theory and Language Poetry," Pembroke Magazine 28 (1996): 64-87.

30 Meindl. "Die Gegenwartsliteratur der USA" 28. 
equally one-sided sociopolitical poems in the wake of Bertolt Brecht had bee rampant in the late 1960s and a good deal of the 1970s, a wholly new movement, after some wavering back and forth had nonchalantly established itself by 1980 . Yet can it really be called a 'movement' at all? What is this alleged 'New Subjectivity' (as it proudly labeled itself, or was labeled by eager critics) other than a formless, unrestrained, and totally private and personal outpouring of marginal babble and prattle--in most of its numerous instances, at any rate--or else, in the hands of gifted poets such as Jurgen Becker and Nicolas Born, a highly problematic lyrical practice both in the first place and in the long run? ${ }^{31}$ For even to them, the shibboleth of poetic creation appears to have been an indiscriminate notion like 'anything goes.' As Rolf Dieter Brinkmann, one or the fiercest and most determined proponents of such verses and non-verses, phrased it as early as 1969 :

Each and everything [schlechthin alles] that one perceives or that one deals with can be made into a poem, provided one views it with adequate exactitude and renders it with adequate directness.

And this rather cheeky confession, mind you, expressly and gratefully refers to a modern American poet: namely, to Frank O'Hara. ${ }^{32}$ Still, German poésie pure, at one

${ }^{31}$ For an early and both critical and historical evaluation, compare Hiltrud Gnug, "The Supposedly New Subjectivity: On German Lyric Poetry of the Late Seventies," in From Ode to Anthem 182-92.

32 "Dankbar bin ich . . . den Gedichten Frank O' Haras, die mir gezeigt haben, daß schlechthin end of the spectrum, and German poésie engagée, at the other, have continued near unabatedly nonetheless, as have the countless structural and thematic manifestations and variations of verse extending in between. Once again, then, the rest is diversity.

Hence, what are the results we have ultimately achieved by way of our fleeting sidelights on contemporary Western poetry? Am I advocating a sort of wishy-washy mishmash, after all? The answer cannot but be a resounding No! To avail myself of a pertinent dictum from the work of Benn, an autobiographical and truly programmatic statement dating back to the year 1949:

Aber wenn der Mann danach ist, dann kann der erste Vers aus der Kursbuch sein und der zweite eine Gesangbuchstrophe und der dritte ein Mikoschwitz und das Ganze ist doch ein Gedicht. ${ }^{33}$ alles, was man sieht und womit man sich beschaftigt, wenn man es nur genau genug sieth und direkt genug wiedergibt, ein Gedicht werden kann ..." ; Rolf Dieter Brinkmann as quoted in Klaus Schuhmann, Lyrik des 20. Jahrhunderts : Materialien zu einer Poetik (Reinbek bei Hamburg : Rowohlt Taschenbuch Verlag, 1995) $339 f$.

${ }^{33}$ Gottfired Benn, Gesammelte Werke in vier Banden, hg. Dieter Wellershoff (Wiesbaden: Limes, 1958ff.) IV: 164; cf. also ibid. 448. The respective chapter, which is dated "6/9/1949," bears the oddly reversed title "Zukunft und Gegenwart" ("Future and Present"). bears the oddly reversed title "Zukunft und Gegenwart" ("Future and Present"). 
Of necessity, the translation of this marvelous definition boils down to a mere approximation:

Yet if the poet is competent enough (has the stature, the talent, the felicitous touch), then the first line may stem from the railroad time table and the second from a church hymn while the third may be a silly or dirty joke, and the whole thing will still amount to a poem.

In short, it is the great poet who produces great poetry, today as always, in Western or non-Western literature, and regardless of any doctrines whatsoever. 